\title{
Violence a global public health problem ${ }^{\star}$
}

\author{
Violência como um problema global de saúde pública
}

Linda L. Dahlberg 1 Etienne G. Krug 1

\footnotetext{
* Version of the

Introduction to the World Report on Violence and Health (WHO): Geneve: WHO, 2002, authorized by the authors.

1 Division of Violence Prevention, National Center for Injury Prevention and Control, Centers for Disease Control and Prevention, WHO.

Atlanta GA.

ldahlberg@cdc.gov
}

Resumo Este artigo é uma versão do que foi publicado no Informe Mundial sobre Violência e Saúde da Organização Mundial de Saúde, como introdução ao tema. Apresenta uma descrição geral da problemática e a posição da OMS. Nele os autores se dedicam a responder algumas questões básicas: o estado do conhecimento sobre o assunto; os conceitos e definições com os quais a OMS trabalha; a natureza e a tipologia sobre violência; as formas de abordagem quantitativa e qualitativa em um modelo ecológico; o lugar e o papel da saúde pública e sua potencialidade com vistas a contribuir para prevenir e diminuir a violência no mundo; as responsabilidades das nações e dos gestores em todos os níveis; os obstáculos para atuação e os desafios para o setor.

Palavras-chave Violência e saúde, Informe Mundial sobre Violência e Saúde, Causas externas
Key words Violence and health, World Report on Violence and Health, External causes 


\section{Background}

Violence has probably always been part of the human experience. Its impact can be seen, in various forms, in all parts of the world. Each year, more than a million people lose their lives, and many more suffer non-fatal injuries, as a result of self-inflicted, interpersonal or collective violence. Overall, violence is among the leading causes of death worldwide for people aged 15-44 years.

Although precise estimates are difficult to obtain, the cost of violence translates into billions of US dollars in annual health care expenditures worldwide, and billions more for national economies in terms of days lost from work, law enforcement and lost investment.

The human cost in grief and pain, of course, cannot be calculated. In fact, much of it is almost invisible. While satellite technology has made certain types of violence - terrorism, wars, riots and civil unrest - visible to television audiences on a daily basis, much more violence occurs out of sight in homes, workplaces and even in the medical and social institutions set up to care for people. Many of the victims are too young, weak or ill to protect themselves. Others are forced by social conventions or pressures to keep silent about their experiences.

As with its impacts, some causes of violence are easy to see. Others are deeply rooted in the social, cultural and economic fabric of human life. Recent research suggests that while biological and other individual factors explain some of the predisposition to aggression, more often these factors interact with family, community, cultural and other external factors to create a situation where violence is likely to occur.

Despite the fact that violence has always been present, the world does not have to accept it as an inevitable part of the human condition. As long as there has been violence, there have also been systems - religious, philosophical, legal and communal - which have grown up to prevent or limit it. None has been completely successful, but all have made their contribution to this defining mark of civilization.

Since the early 1980s, the field of public health has been a growing asset in this response. A wide range of public health practitioners, researchers and systems have set themselves the tasks of understanding the roots of violence and preventing its occurrence.

Violence can be prevented and its impact reduced, in the same way that public health ef- forts have prevented and reduced pregnancyrelated complications, workplace injuries, infectious diseases, and illness resulting from contaminated food and water in many parts of the world. The factors that contribute to violent responses - whether they are factors of attitude and behaviour or related to larger social, economic, political and cultural conditions can be changed.

Violence can be prevented. This is not an article of faith, but a statement based on evidence. Examples of success can be found around the world, from small-scale individual and community efforts to national policy and legislative initiatives.

\section{What can a public health approach contribute?}

By definition, public health is not about individual patients. Its focus is on dealing with diseases and with conditions and problems affecting health and it aims to provide the maximum benefit for the largest number of people. This does not mean that public health ignores the care of individuals. Rather, the concern is to prevent health problems and to extend better care and safety to entire populations.

The public health approach to any problem is interdisciplinary and science-based ${ }^{1}$. It draws upon knowledge from many disciplines, including medicine, epidemiology, sociology, psychology, criminology, education and economics. This has allowed the field of public health to be innovative and responsive to a wide range of diseases, illnesses and injuries around the world.

The public health approach also emphasizes collective action. It has proved time and again that cooperative efforts from such diverse sectors as health, education, social services, justice and policy are necessary to solve what are usually assumed to be purely "medical" problems. Each sector has an important role to play in addressing the problem of violence and, collectively, the approaches taken by each have the potential to produce important reductions in violence.

The public health approach to violence is based on the rigorous requirements of the scientific method. In moving from problem to solution, it has four key steps: 1) uncovering as much basic knowledge as possible about all the 
aspects of violence - through systematically collecting data on the magnitude, scope, characteristics and consequences of violence at local, national and international levels; 2) investigating why violence occurs, that is, conducting research to determine: the causes and correlates of violence; the factors that increase or decrease the risk for violence; the factors that might be modifiable through interventions; 3 ) exploring ways to prevent violence, using the information from the above, by designing, implementing, monitoring and evaluating interventions; 4) implementing, in a range of settings, interventions that appear promising, widely disseminating information and determining the cost-effectiveness of programmes.

Public health is above all characterized by its emphasis on prevention. Rather than simply accepting or reacting to violence, its starting point is the strong conviction that violent behaviour andits consequences can be prevented.

\section{Defining violence}

Any comprehensive analysis of violence should begin by defining the various forms of violence in such a way as to facilitate their scientific measurement. There are many possible ways to define violence. The World Health Organization defines violence ${ }^{2}$ as: the intentional use of physical force or power, threatened or actual, against oneself, another person, or against a group or community that either results in or has a high likelihood of resulting in injury, death, psychological harm, maldevelopment or deprivation.

The definition used by the World Health Organization associates intentionality with the committing of the act itself, irrespective of the outcome it produces. Excluded from the definition are unintentional incidents - such as most road traffic injuries and burns.

The inclusion of the word "power", in addition to the phrase "use of physical force", broadens the nature of a violent act and expands the conventional understanding of violence to include those acts that result from a power relationship, including threats and intimidation. The "use of power" also serves to include neglect or acts of omission, in addition to the more obvious violent acts of commission. Thus, "the use of physical force or power" should be understood to include neglect and all types of physical, sexual and psy- chological abuse, as well as suicide and other self-abusive acts.

This definition covers a broad range of outcomes - including psychological harm, deprivation and maldevelopment. This reflects a growing recognition among researchers and practitioners of the need to include violence that does not necessarily result in injury or death, but that nonetheless poses a substantial burden on individuals, families, communities and health care systems worldwide. Many forms of violence against women, children and the elderly, for instance, can result in physical, psychological and social problems that do not necessarily lead to injury, disability or death. These consequences can be immediate, as well as latent, and can last for years after the initial abuse. Defining outcomes solely in terms of injury or death thus limits the understanding of the full impact of violence on individuals, communities and society at large.

One of the more complex aspects of the definition is the matter of intentionality. Two important points about this should be noted. First, even though violence is distinguished from unintended events that result in injuries, the presence of an intent to use force does not necessarily mean that there was an intent to cause damage. Indeed, there may be a considerable disparity between intended behaviour and intended consequence. A perpetrator may intentionally commit an act that, by objective standards, is judged to be dangerous and highly likely to result in adverse health effects, but the perpetrator may not perceive it as such.

As examples, a youth may be involved in a physical fight with another youth. The use of a fist against the head or the use of a weapon in the dispute certainly increases the risk of serious injury or death, though neither outcome may be intended. A parent may vigorously shake a crying infant with the intent to quieten it. Such an action, however, may instead cause brain damage. Force was clearly used, but without the intention of causing an injury.

A second point related to intentionality lies in the distinction between the intent to injure and the intent to "use violence". Violence, according to Walters \& Parke $^{3}$, is culturally determined. Some people mean to harm others but, based on their cultural backgrounds and beliefs, do not perceive their acts as violent. The definition used by the World Health Organization, however, defines violence as it relates to the health or well-being of individuals. 
Certain behaviours - such as hitting a spouse - may be regarded by some people as acceptable cultural practices, but are considered violent acts with important health implications for the individual.

Other aspects of violence, though not explicitly stated, are also included in the definition. For example, the definition implicitly includes all acts of violence, whether they are public or private, whether they are reactive (in response to previous events such as provocation) or proactive (instrumental for or anticipating more self-serving outcomes 4 ), or whether they are criminal or noncriminal. Each of these aspects is important in understanding the causes of violence and in designing prevention programmes.

\section{Typology of violence}

In its 1996 resolution WHA49.25, declaring violence a leading public health problem, the World Health Assembly called on the World Health Organization to develop a typology of violence that characterized the different types of violence and the links between them. Few typologies exist already and none is very comprehensive 5 .

The typology proposed here divides violence into three broad categories according to characteristics of those committing the violent act: 1) self-directed violence; b) interpersonal violence; c) collective violence.

This initial categorization differentiates between violence a person inflicts upon himself or herself, violence inflicted by another individual or by a small group of individuals, and violence inflicted by larger groups such as states, organized political groups, militia groups and terrorist organizations.

These three broad categories are each divided further to reflect more specific types of violence.

- Self-directed violence is subdivided into suicidal behaviour and self-abuse. The former includes suicidal thoughts, attempted suicides also called "parasuicide" or "deliberate self-injury" in some countries - and completed suicides. Self-abuse, in contrast, includes acts such as self-mutilation.

- Interpersonal violence is divided into two subcategories: 1) family and intimate partner violence - that is, violence largely between family members and intimate partners, usually, though not exclusively, taking place in the home.

- Community violence - violence between individuals who are unrelated, and who may or may not know each other, generally taking place outside the home.

The former group includes forms of violence such as child abuse, intimate partner violence and abuse of the elderly. The latter includes youth violence, random acts of violence, rape or sexual assault by strangers, and violence in institutional settings such as schools, workplaces, prisons and nursing homes.

Collective violence is subdivided into social, political and economic violence. Unlike the other two broad categories, the subcategories of collective violence suggest possible motives for violence committed by larger groups of individuals or by states. Collective violence that is committed to advance a particular social agenda includes, for example, crimes of hate committed by organized groups, terrorist acts and mob violence. Political violence includes war and related violent conflicts, state violence and similar acts carried out by larger groups. Economic violence includes attacks by larger groups motivated by economic gain - such as attacks carried out with the purpose of disrupting economic activity, denying access to essential services, or creating economic division and fragmentation. Clearly, acts committed by larger groups can have multiple motives.

\section{The nature of violent acts}

Figure 1 illustrates the nature of violent acts, which can be: 1) physical; 2) sexual; 3) psychological; 4) involving deprivation or neglect. The horizontal array in figure 1 shows who is affected, and the vertical array describes how they are affected.

These four types of violent acts occur in each of the broad categories and their subcategories described above - with the exception of self-directed violence. For instance, violence against children committed within the home can include physical, sexual and psychological abuse, as well as neglect. Community violence can include physical assaults between young people, sexual violence in the workplace and neglect of older people in long-term care facilities. Political violence can include such acts as rape during conflicts, and physical and psychological warfare. 


\section{Figure 1}

A typology of violence.

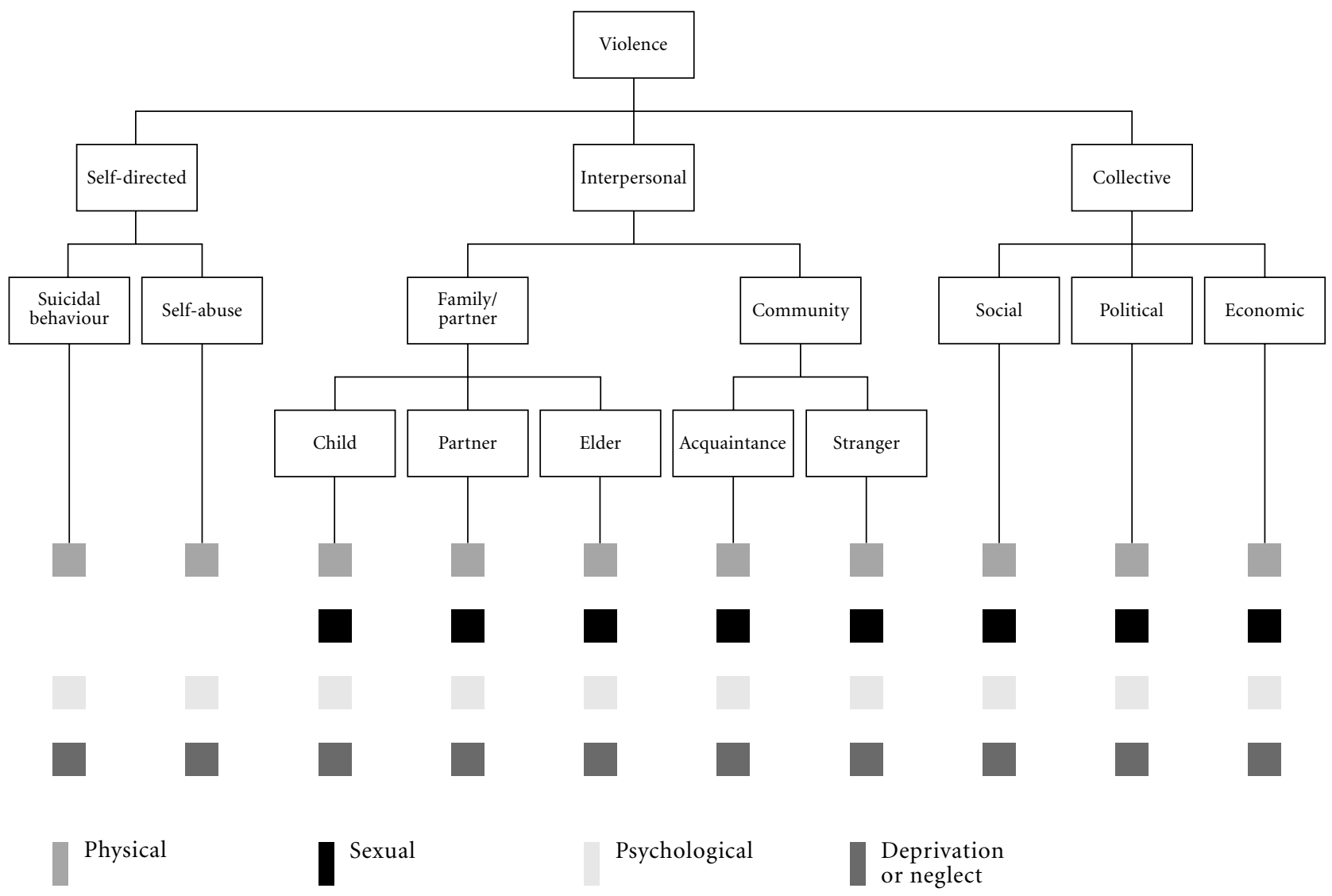

This typology, while imperfect and far from being universally accepted, does provide a useful framework for understanding the complex patterns of violence taking place around the world, as well as violence in the everyday lives of individuals, families and communities. It also overcomes many of the limitations of other typologies by capturing the nature of violent acts, the relevance of the setting, the relationship between the perpetrator and the victim, and - in the case of collective violence - possible motivations for the violence. However, in both research and practice, the dividing lines between the different types of violence are not always so clear.

\section{Measuring violence and its impact}

Different types of data are needed for different purposes, including: 1) describing the magni- tude and impact of violence; 2) understanding which factors increase the risk for violent victimization and perpetration; 3 ) knowing how effective violence prevention programmes are. Some of these types of data and sources are described in table 1 .

Data on fatalities, particularly through homicide, and on suicide and war-related deaths can provide an indication of the extent of lethal violence in a particular community or country. When compared to statistics on other deaths, such data are useful indicators of the burden created by violence-related injuries. These data can also be used for monitoring changes over time in fatal violence, identifying groups and communities at high risk of violence, and making comparisons within and between countries.

Mortality figures, however, are only one possible type of data for describing the magni- 
Table 1

Types of data and potential sources for collecting information.

\begin{tabular}{|c|c|c|}
\hline Type of data & Data sources & Examples of information collected \\
\hline Mortality & $\begin{array}{l}\text { Death certificates, vital statistics } \\
\text { registries, medical examiners', } \\
\text { coroners' or mortuary reports }\end{array}$ & $\begin{array}{l}\text { Characteristics of the decedent, } \\
\text { cause of death, location, time, } \\
\text { manner of death }\end{array}$ \\
\hline $\begin{array}{l}\text { Morbidity and } \\
\text { other health data }\end{array}$ & $\begin{array}{l}\text { Hospital, clinic or other medical } \\
\text { records }\end{array}$ & $\begin{array}{l}\text { Diseases, injuries, information on } \\
\text { physical, mental or reproductive } \\
\text { health }\end{array}$ \\
\hline Self-reported & $\begin{array}{l}\text { Surveys, special studies, } \\
\text { focus groups, media }\end{array}$ & $\begin{array}{l}\text { Attitudes, beliefs, behaviours, } \\
\text { cultural practices, victimization and } \\
\text { perpetration, exposure to violence } \\
\text { in the home or community }\end{array}$ \\
\hline Community & $\begin{array}{l}\text { Population records, local } \\
\text { government records, other } \\
\text { institutional records }\end{array}$ & $\begin{array}{l}\text { Population counts and density, } \\
\text { levels of income and education, } \\
\text { unemployment rates, divorce rates }\end{array}$ \\
\hline Crime & $\begin{array}{l}\text { Police records, judiciary records, } \\
\text { crime laboratories }\end{array}$ & $\begin{array}{l}\text { Type of offence, characteristics of } \\
\text { offender, relationship between victim } \\
\text { and offender, circumstances of event }\end{array}$ \\
\hline Economic & $\begin{array}{l}\text { Programme, institutional or agency } \\
\text { records, special studies }\end{array}$ & $\begin{array}{l}\text { Expenditures on health, housing } \\
\text { or social services, costs of treating } \\
\text { violence-related injuries, use } \\
\text { of services }\end{array}$ \\
\hline Policy or legislative & Government or legislative records & $\begin{array}{l}\text { Laws, institutional policies } \\
\text { and practices }\end{array}$ \\
\hline
\end{tabular}

tude of the problem. Since non-fatal outcomes are much more common than fatal outcomes and because certain types of violence are not fully represented by mortality data, other types of information are necessary. Such information can help in understanding the circumstances surrounding specific incidents and in describing the full impact of violence on the health of individuals and communities. These types of data include: health data on diseases, injuries and other health conditions; self-reported data on attitudes, beliefs, behaviours, cultural practices, victimization and exposure to violence; community data on population characteristics and levels of income, education and unemployment; crime data on the characteristics and circumstances of violent events and violent offenders; economic data related to the costs of treatment and social services; data describing the economic burden on health care systems and possible savings realized from prevention programmes; data on policy and legislation.
Potential sources of the various types of information include: individuals; agency or institutional records; local programmes; community and government records; population-based and other surveys; special studies.

Though not listed in table 1 , almost all sources include basic demographic information - such as a person's age and sex. Some sources - including medical records, police records, death certificates and mortuary reports - include information specific to the violent event or injury. Data from emergency departments, for instance, may provide information on the nature of an injury, how it was sustained, and when and where the incident occurred. Data collected by the police may include information on the relationship between the victim and the perpetrator, whether a weapon was involved, and other circumstances related to the offence.

Surveys and special studies can provide detailed information about the victim or perpetra- 
tor, and his or her background, attitudes, behaviours and possible previous involvement in violence. Such sources can also help uncover violence that is not reported to the police or other agencies. For example, a house-hold survey in the South Africa showed that between 50\% and $80 \%$ of victims of violence received medical treatment for a violence-related injury without reporting the incident to the police ${ }^{6}$. In another study, conducted in the United States of America, $46 \%$ of victims who sought emergency treatment did not make a report to the police.

The availability, quality and usefulness of the different data sources for comparing types of violence within and between countries vary considerably. Countries around the world are at very different stages with regard to their capacity for data collection?

Mortality data are the most widely collected and available of all sources of data. Many countries maintain birth and death registries and keep basic counts of homicides and suicides. Calculating rates from these basic counts, however, is not always possible because population data are often unavailable or unreliable. This is especially true where populations are in flux - in areas, for instance, experiencing conflict or continuous movements among population groups - or where populations are difficult to count, as is the case in densely populated or very remote areas. Systematic data on non-fatal outcomes are not available in most countries of the world, though systems to collect such data are currently being developed. A number of documents providing guidance for measuring different types of violence in a range of settings have also been published in recent years $8,9,10,11,12,13,14$.

Even when data are available, the quality of the information may be inadequate for research purposes and for identifying strategies for prevention. Given that agencies and institutions keep records for their own purposes, following their own internal procedures for record-keeping, their data may be incomplete or lack the kind of information necessary for a proper understanding of violence.

Data from health care facilities, for instance, are collected with a view to providing optimal treatment for the patient. The medical record may contain diagnostic information about the injury and course of treatment, but not the circumstances surrounding the injury. These data may also be confidential and thus not available for research purposes. Surveys, on the other hand, contain more detailed information about the person and his or her background and involvement in violence. They are limited, though, by the extent to which a person recalls events and admits to engaging in certain behaviours, and also by the manner in which questions are asked and by whom they are asked - as well as when, where and how well the interview is conducted.

Linking data across sources is one of the more difficult problems in research on violence. Data on violence generally come from a variety of organizations that operate independently of one another. As such, data from medical examiners and coroners cannot usually be linked to data collected by the police. Also, there is a general lack of uniformity in the way data on violence are collected, which makes it very difficult to compare data across communities and nations.

Although they are beyond the scope of this discussion, a number of other problems in collecting violence-related data should be mentioned. They include: 1) the difficulty of developing measures that are relevant and specific to subpopulation groups and different cultural contexts $8,9,11,14 ; 2$ ) devising appropriate protocols to protect the confidentiality of victims and ensure their safety $15 ; 3$ ) a range of other ethical considerations associated with research into violence.

\section{An overview of current knowledge}

The prevention of violence, according to the public health approach, begins with a description of the magnitude and impact of the problem. This section describes what is currently known about global patterns of violence, using data compiled for this report from the World Health Organization's mortality database and Version 1 of the World Health Organization's Global Burden of Disease project for 2000, as well as data from surveys and special studies of violence.

In 2000, an estimated 1.6 million people worldwide died as a result of self-inflicted, interpersonal or collective violence, for an overall age-adjusted rate of 28.8 per 100,000 population (see Table 2).

The vast majority of these deaths occurred in low- to middle-income countries. Less than $10 \%$ of all violence-related deaths occurred in high-income countries. Nearly half of these 1.6 
Table 2

Estimated global violence-related deaths, 2000.

\begin{tabular}{lccc}
\hline Type of violence & Number & $\begin{array}{c}\text { Rate per 100,000 } \\
\text { population }\end{array}$ & $\begin{array}{c}\text { Proportion } \\
\text { of total (\%) }\end{array}$ \\
\hline Homicide & 520,000 & 8.8 & 31.3 \\
Suicide & 815,000 & 14.5 & 49.1 \\
War-related & 310,000 & 5.2 & 18.6 \\
Totalc & $1,659,000$ & 28.8 & 100.0 \\
Low-to middle-income countries & $1,510,000$ & 32.1 & 91.1 \\
High-income countries & 149,000 & 14.4 & 8.9 \\
\hline
\end{tabular}

Source: WHO Global Burden of Disease project for 2000, Version 1 (see Statistical annex).

a Rounded to the nearest 1,000 .

b Age-standardized.

${ }^{\mathrm{c}}$ Includes 14,000 intentional injury deaths resulting from legal intervention.

million violence-related deaths were suicides, almost one-third were homicides and about one-fifth were war-related.

Like many other health problems in the world, violence is not distributed evenly among sex or age groups. In 2000, there were an estimated 520,000 homicides, for an overall ageadjusted rate of 8.8 per 100,000 population (see Table 2). Males accounted for $77 \%$ of all homicides and had rates that were more than three times those of females (13.6 and 4.0, respectively, per 100,000) (see Table 3 ). The highest rates of homicide in the world are found among males aged 15-29 years (19.4 per $100,000)$, followed closely by males aged 30-44 years $(18.7$ per 100,000$)$. Worldwide, suicide claimed the lives of an estimated 815,000 people in 2000 , for an overall age-adjusted rate of 14.5 per 100,000 (see Table 2 ). Over $60 \%$ of all suicides occurred among males, over half of these occurring among those aged 15-44 years. For both males and females, suicide rates increase with age and are highest among those aged 60 years and older (see Table 3 ). Suicide rates, though, are generally higher among males than females (18.9 per 100,000 as against 10.6 per 100,000 ). This is especially true among the oldest age groups, where worldwide, male suicide rates among those aged 60 years and older are twice as high as female suicide rates in the same age category ( 44.9 per 100,000 as against 22.1 per 100,000$)$.

\section{Mortality according to country income level and region}

Rates of violent death vary according to country income levels. In 2000, the rate of vio- lent death in low- to middle-income countries was 32.1 per 100,000 population, more than twice the rate in high-income countries (14.4 per 100,000) (see Table 2).

There are also considerable regional differences in rates of violent death. These differences are evident, for example, among the WHO regions. In the African Region and the Region of the Americas, homicide rates are nearly three times greater than suicide rates.

However, in the European and South-East Asia Regions, suicide rates are more than double homicide rates ( 19.1 per 100,000 as against 8.4 per 100,000 for the European Region, and 12.0 per 100,000 as against 5.8 per 100,000 for the South-East Asia Region), and in the Western Pacific Region, suicide rates are nearly six times greater than homicide rates $(20.8$ per 100,000 as against 3.4 per 100,000 ).

Within regions there are also large differences between countries. For example, in 1994 the homicide rate among males in Colombia was reported to be 146.5 per 100,000 , while the corresponding rates in Cuba and Mexico were 12.6 and 32.3 per 100,000 , respectively 16 . Large differences within countries also exist between urban and rural populations, between rich and poor groups, and between different racial and ethnic groups. In the United States in 1999, for instance, African-American youths aged 15-24 years had a rate of homicide $(38.6$ per 100,000$)$ more than twice that of their Hispanic counterparts (17.3 per 100,000), and over 12 times the rate of their Caucasian, non-Hispanic counterparts $(3.1$ per 100,000)17.

The above-mentioned mortality figures are almost certainly underestimates of the true burden of violence. In all parts of the world, 
Table 3

Estimated global homicide and suicide rates by age group, 2000.

\begin{tabular}{|c|c|c|c|c|}
\hline \multirow[t]{2}{*}{ Age group (years) } & \multicolumn{2}{|c|}{$\begin{array}{c}\text { Homicide rate } \\
\text { (per } 100,000 \text { population) }\end{array}$} & \multicolumn{2}{|c|}{$\begin{array}{c}\text { Suicide rate } \\
\text { (per } 100,000 \text { population })\end{array}$} \\
\hline & Males & Females & Males & Females \\
\hline $0-4$ & 5.8 & 4.8 & 0.0 & 0.0 \\
\hline $5-14$ & 2.1 & 2.0 & 1.7 & 2.0 \\
\hline $15-29$ & 19.4 & 4.4 & 15.6 & 12.2 \\
\hline $30-44$ & 18.7 & 4.3 & 21.5 & 12.4 \\
\hline $45-59$ & 14.8 & 4.5 & 28.4 & 12.6 \\
\hline$\geq 60$ & 13.0 & 4.5 & 44.9 & 22.1 \\
\hline Totala & 13.6 & 4.0 & 18.9 & 10.6 \\
\hline
\end{tabular}

Source: WHO Global Burden of Disease project for 2000, Version 1 (see Statistical annex).

a Age-standardized.

deaths represent the "tip of the iceberg" as far as violence is concerned. Physical and sexual assaults occur daily, though precise national and international estimates of each are lacking. Not all assaults result in injuries severe enough to require medical attention and - even among those that do result in serious injuries - surveillance systems for reporting and compiling these injuries are in many countries either lacking or are still being developed.

Much of what is known about non-fatal violence comes from surveys and special studies of different population groups. For example, in national surveys, the percentage of women who reported ever being physically assaulted by an intimate partner ranged from 10\% in Paraguay and the Philippines, to $22.1 \%$ in the United States, $29.0 \%$ in Canada and $34.4 \%$ in Egypt 18 , $19,20,21$. The proportion of women from various cities or provinces around the world reporting ever having been sexually assaulted (including victims of attempted assault) varied from $15.3 \%$ inToronto, Canada, to $21.7 \%$ in León, Nicaragua, $23.0 \%$ in London, England, and $25.0 \%$ in one province in Zimbabwe 21, 22, $23,24,25$. Among adolescent males in secondary schools, the percentage reporting involvement in physical fighting in the past year ranged from $22.0 \%$ in Sweden and $44.0 \%$ in the United States to $76.0 \%$ in Jerusalem, Israel26, 27, 28 .

An important point here is that these data are based largely on self-reports. It is difficult to know whether they overestimate or underestimate the true extent of physical and sexual assaults among these population groups. Certainly, in those countries with strong cultural pressures to keep violence "behind closed doors" or simply to accept it as "natural", non-fatal vio- lence is likely to be underreported. Victims may be reluctant to discuss violent experiences not only out of shame and because of taboos, but through fear. Admitting to having experienced certain violent events, such as rape, may in some countries result in death. In certain cultures, the preservation of family honour is a traditional motive for killing women who have been raped (so-called "honour killings").

\section{The costs of violence}

Violence exacts both a human and an economic toll on nations, and costs economies many billions of US dollars each year in health care, legal costs, absenteeism from work and lost productivity. In the United States, a 1992 study estimated the direct and indirect annual costs of gunshot wounds at US\$ 126 billion. Cutting or stab wounds cost an additional US\$ 51 billion ${ }^{29}$. In a 1996 study in the Canadian province of New Brunswick, the mean total cost per suicide death was over US\$ 849,000 . The total direct and indirect costs, including costs for health careservices, autopsies, police investigations and lost productivity resulting from premature death, amounted to nearly US\$ 80 million 30 .

The high cost of violence is not unique to Canada and the United States. Between 1996 and 1997, the Inter-American Development Bank sponsored studies on the magnitude and economic impact of violence in six Latin American countries ${ }^{31}$. Each study examined expenditures, as a result of violence, for health care services, law enforcement and judicial services, as well as intangible losses and losses from the 
transfer of assets. Expressed as a percentage of the gross domestic product (GDP) in 1997, the cost of health care expenditures arising from violence was $1.9 \%$ of the GDP in Brazil, $5.0 \%$ in Colombia, $4.3 \%$ in El Salvador, $1.3 \%$ in Mexico, $1.5 \%$ in Peru, and $0.3 \%$ in Venezuela.

It is difficult to calculate the precise burden of all types of violence on health care systems, or their effects on economic productivity around the world. The available evidence shows that victims of domestic and sexual violence have more health problems, significantly higher health care costs and more frequent visits to emergency departments throughout their lives than those without a history of abuse. The same is true for victims of childhood abuse and neglect. These costs contribute substantially to annual health care expenditures.

Since national cost estimates are also generally lacking for other health problems, such as depression, smoking, alcohol and drug abuse, unwanted pregnancy, human immunodeficiency virus/acquired immunodeficiency syndrome (HIV/AIDS), other sexually transmitted diseases and other infections (all of which have been linked to violence in small-scale studies) $32,33,34,35,36,37$, it is not yet possible to calculate the global economic burden of these problems as they relate to violence.

\section{Examining the roots of violence: an ecological model}

No single factor explains why some individuals behave violently toward others or why violence is more prevalent in some communities than in others. Violence is the result of the complex interplay of individual, relationship, social, cultural and environmental factors. Understanding how these factors are related to violence is one of the important steps in the public health approach to preventing violence.

The chapters in this report apply an ecological model to help understand the multifaceted nature of violence. First introduced in the late $1970 s^{38,39}$, this ecological model was initially applied to child abuse and subsequently to youth violence 40,41 . More recently, researchers have used it to understand intimate partner violence ${ }^{42,43}$ and abuse of the elderly 44,45 . The model explores the relationship between individual and contextual factors and considers violence as the product of multiple levels of influence on behaviour (see Figure 2).

The first level of the ecological model seeks to identify the biological and personal history factors that an individual brings to his or her behaviour. In addition to biological and demographic factors, factors such as impulsivity, low

\section{Figure 2}

Ecological model for understanding violence.

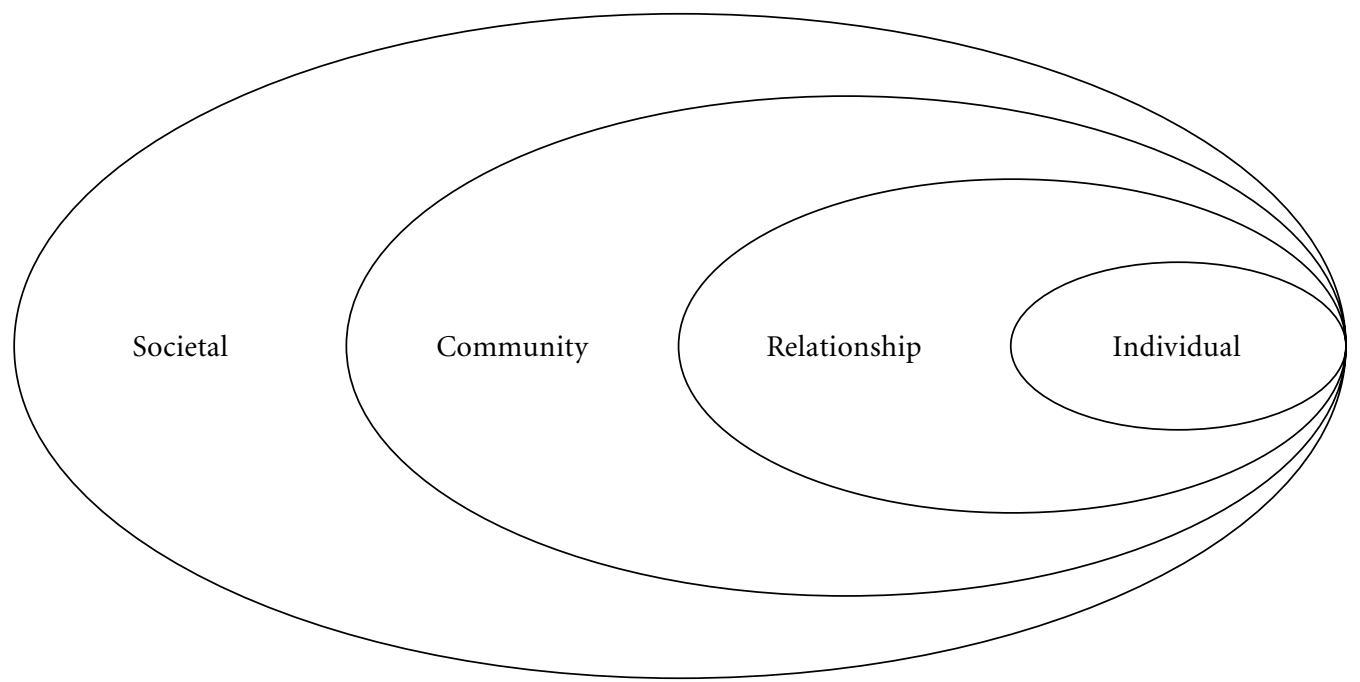


educational attainment, substance abuse, and prior history of aggression and abuse are considered. In other words, this level of the ecological model focuses on the characteristics of the individual that increase the likelihood of being a victim or a perpetrator of violence.

The second level of the ecological model explores how proximal social relationships for example, relations with peers, intimate partners and family members - increase the risk for violent victimization and perpetration of violence. In the cases of partner violence and child maltreatment, for instance, interacting on an almost daily basis or sharing a common domicile with an abuser may increase the opportunity for violent encounters. Because individuals are bound together in a continuing relationship, it is likely in these cases that the victim will be repeatedly abused by the offender ${ }^{46}$. In the case of interpersonal violence among youths, research shows that young people are much likely to engage in negative activities when those behaviours are encouraged and approved by their friends 47,48 . Peers, intimate partners and family members all have the potential to shape an individual's behaviour and range of experience.

The third level of the ecological model examines the community contexts in which social relationships are embedded - such as schools, workplaces and neighbourhoods - and seeks to identify the characteristics of these settings that are associated with being victims or perpetrators of violence. A high level of residential mobility (where people do not stay for a long time in a particular dwelling, but move many times), heterogeneity (highly diverse population, with little of the social "glue" that binds communities together) and high population density are all examples of such characteristics and each has been associated with violence. Similarly, communities characterized by problems such as drug trafficking, high levels of unemployment or widespread social isolation (for example, people not knowing their neighbours or having no involvement in the local community) are also more likely to experience violence. Research on violence shows that opportunities for violence are greater in some community contexts than others - for instance, in areas of poverty or physical deterioration, or where there are few institutional supports.

The fourth and final level of the ecological model examines the larger societal factors that influence rates of violence. Included here are those factors that create an acceptable climate for violence, those that reduce inhibitions against violence, and those that create and sustain gaps between different segments of society - or tensions between different groups or countries. Larger societal factors include: 1) cultural norms that support violence as an acceptable way to resolve conflicts; 2) attitudes that regard suicide as a matter of individual choice instead of a preventable act of violence; 3 ) norms that give priority to parental rights over child welfare; 4 ) norms that entrench male dominance over women and children; 5) norms that support the use of excessive force by police against citizens; 6) norms that support political conflict.

Larger societal factors also include the health, educational, economic and social policies that maintain high levels of economic or social inequality between groups in society.

The ecological framework highlights the multiple causes of violence and the interaction of risk factors operating within the family and broader community, social, cultural and economic contexts. Placed within a developmental context, the ecological model also shows how violence may be caused by different factors at different stages of life.

While some risk factors may be unique to a particular type of violence, the various types of violence more commonly share a number of risk factors. Prevailing cultural norms, poverty, social isolation and such factors as alcohol abuse, substance abuse and access to firearms are risk factors for more than one type of violence. As a result, it is not unusual for some individuals at risk of violence to experience more than one type of violence. Women at risk of physical violence by intimate partners, for example, are also at risk of sexual violence ${ }^{18}$.

It is also not unusual to detect links between different types of violence. Research has shown that exposure to violence in the home is associated with being a victim or perpetrator of violence in adolescence and adulthood 49 . The experience of being rejected, neglected or suffering indifference at the hands of parents leaves children at greater risk for aggressive and antisocial behaviour, including abusive behaviour as adults $50,51,52$. Associations have been found between suicidal behaviour and several types of violence, including child maltreatment 53,54 , intimate partner violence ${ }^{33,55}$, sexual assault ${ }^{53}$ and abuse of the elderly56, 57. In Sri Lanka, suicide rates were shown to decrease during wartime, 
only to increase again after the violent conflict ended 58 . In many countries that have suffered violent conflict, the rates of interpersonal violence remain high even after the cessation of hostilities - among other reasons because of the way violence has become more socially accepted and the availability of weapons.

The links between violence and the interaction between individual factors and the broader social, cultural and economic contexts suggest that addressing risk factors across the various levels of the ecological model may contribute to decreases in more than one type of violence.

\section{How can violence be prevented?}

The first two steps of the public health model provide important information about populations requiring preventive interventions, as well as on the risk and protective factors that need addressing. Putting this knowledge into practice is a central goal of public health.

Public health interventions are traditionally characterized in terms of three levels of prevention:

- Primary prevention - approaches that aim to prevent violence before it occurs.

- Secondary prevention - approaches that focus on the more immediate responses to violence, such as pre-hospital care, emergency services or treatment for sexually transmitted diseases following a rape.

- Tertiary prevention - approaches that focus on long-term care in the wake of violence, such as rehabilitation and reintegration, and attempts to lessen trauma or reduce the longterm disability associated with violence.

These three levels of prevention are defined by their temporal aspect - whether prevention takes place before violence occurs, immediately afterwards or over the longer term. Although traditionally they are applied to victims of violence and within health care settings, secondary and tertiary prevention efforts have also been regarded as having relevance to the perpetrators of violence, and applied in judicial settings in response to violence.

Researchers in the field of violence prevention have increasingly turned to a definition of prevention that focuses on the target group of interest. This definition groups interventions as follows ${ }^{59}$ :

- Universal interventions - approaches aimed at groups or the general population without regard to individual risk; examples include violence prevention curricula delivered to all students in a school or children of a particular age and community-wide media campaigns.

- Selected interventions - approaches aimed at those considered at heightened risk for violence (having one or more risk factors for violence); an example of such an intervention is training in parenting provided to lowincome, single parents.

- Indicated interventions - approaches aimed at those who have already demonstrated violent behaviour, such as treatment for perpetrators of domestic violence.

Many efforts to date, in both industrialized and developing countries, have focused on secondary and tertiary responses to violence. Understandably, priority is often given to dealing with the immediate consequences of violence, providing support to victims and punishing the offenders. Such responses, while important and in need of strengthening, should be accompanied by a greater investment in primary prevention. A comprehensive response to violence is one that not only protects and supports victims of violence, but also promotes non-violence, reduces the perpetration of violence, and changes the circumstances and conditions that give rise to violence in the first place.

Because violence is a multifaceted problem with biological, psychological, social and environmental roots, it needs to be confronted on several different levels at once. The ecological model serves a dual purpose in this regard: each level in the model represents a level of risk and each level can also be thought of as a key point for intervention.

Dealing with violence on a range of levels involves addressing all of the following:

- Addressing individual risk factors and taking steps to modify individual risk behaviours. - Influencing close personal relationships and working to create healthy family environments, as well as providing professional help and support for dysfunctional families.

- Monitoring public places such as schools, workplaces and neighbourhoods and taking steps to address problems that might lead to violence.

- Addressing gender inequality, and adverse cultural attitudes and practices.

- Addressing the larger cultural, social and economic factors that contribute to violence and taking steps to change them, including measures to close the gap between the rich and 
poor and to ensure equitable access to goods, services and opportunities.

A general ground rule for the public health approach to violence is that all efforts, whether large or small, should be rigorously evaluated. Documenting existing responses and encouraging a strictly scientific assessment of interventions in different settings is valuable for everyone. It is particularly needed by others trying to determine the most effective responses to violence and the strategies likely to make a difference.

Bringing together all available evidence and experience is also an extremely useful part of advocacy, as it assures decision-makers that something can be done. Even more importantly, it provides them with valuable guidance as to which efforts are likely to reduce violence.

Rigorous research takes time to produce results. The impulse to invest only in proven approaches should not be an obstacle to supporting promising ones. Promising approaches are those that have been evaluated but require more testing in a range of settings and with different population groups.

There is also wisdom in trying out and testing a variety of programmes, and in using the initiatives and ideas of local communities. Violence is far too pressing a problem to delay public health action while waiting to gain perfect knowledge.

In various parts of the world, cultural specificity and tradition are sometimes given as justifications for particular social practices that perpetuate violence. The oppression of women is one of the most widely quoted examples, but many others can also be given.

Cultural norms must be dealt with sensitively and respectfully in all prevention efforts sensitively because of people's often passionate attachment to their traditions, and respectfully because culture is often a source of protection against violence. Experience has shown that it is important to conduct early and ongoing consultations with religious and traditional leaders, lay groups and prominent figures in the community, such as traditional healers, when designing and implementing programmes.

Long-term successes in the prevention of violence will increasingly depend on comprehensive approaches at all levels.

At the local level, partners may include health care providers, police, educators, social workers, employers and government officials. Much can be done here to promote violence prevention. Smallscale pilot programmes and research projects can provide a means for ideas to be tried out and - perhaps as important for a range of partners to become used to working together. Structures such as working groups or commissions that draw together the different sectors and maintain both formal and informal contacts are essential for the success of this type of collaboration.

Multisectoral partnerships are highly desirable at the national level as much as at the local level. A variety of government ministries - and not only those concerned with law enforcement, social services and health - have important contributions to make in preventing violence. Education ministries are obvious partners, given the importance of intervening in schools. Ministries of labour can do much to reduce violence in the workplace, especially in collaboration with trade unions and employers. Defence ministries can positively shape the attitudes towards violence of large numbers of young men under their control, by encouraging discipline, promoting codes of honour, and impressing a strong awareness of the lethalness of weapons. Religious leaders and organizations have a role to play in their pastoral work and, in appropriate cases, by offering their good offices to mediate in specific problems.

As has been shown, for instance, in the international response to AIDS and in the field of disaster relief, cooperation and exchange of information between organizations globally can produce significant benefits - in the same way as partnerships at the national and local levels. The World Health Organization clearly has an important global role to play in this respect as the United Nations agency responsible for health. Other international agencies, though, also have a considerable amount to offer in their specialized fields. These include the Office of the United Nations High Commissioner for Human Rights (in relation to human rights), the Office of the United Nations High Commissioner for Refugees (refugees), the United Nations Children's Fund (children's well-being), the United Nations Development Fund for Women and the United Nations Population Fund (women's health), the United Nations Development Programme (human development), the United Nations Interregional Crime and Justice Research Institute (crime) and the World Bank (financing and governance), to name just a few. A variety of international donors, bilateral programmes, 
nongovernmental organizations and religious organizations are already involved in violence prevention activities around the world.

If violence is largely preventable, the question arises: why are there not more efforts to prevent it, particularly at national or provincial and state level?

A major obstacle is simply an absence of knowledge. For many decision-makers, the idea that violence is a public health problem is new - and indeed rather contrary to their belief that violence is a crime problem. This is particularly the case for the less visible forms of violence, such as abuse of children, women and the elderly. The notion that violence is preventable is also new or questionable for decision-makers. To many people in authority, a violence-free society seems unobtainable; an "acceptable" level of violence, especially on the streets where they live, appears far more realistic. To others, paradoxically, the inverse is true: since much of violence is hidden, distant or sporadic, peace and security seem to them the prevalent state. In the same way that clean air is taken for granted until the sky becomes full of smog, violence only has to be dealt with when it arrives on the doorstep. It is not surprising then that some of the most innovative solutions have come from the community and municipal levels of government - precisely those that are closest to the problem on a daily basis.

A second problem relates to the feasibility of policy options to tackle the problem. Not enough decision-makers have seen the evidence that many forms of violence are preventable. Too many of them feel that the traditional approaches of the criminal justice system are the only ones that "work". Such a view fails to acknowledge the range of violence in society. It perpetuates the concentration on certain highly visible forms of violence - notably youth violence - while paying much less attention to other types, such as intimate partner violence and abuse of children and the elderly, where the criminal justice system is less responsive and less effective.
A third problem is one of determination. Violence is an extremely emotional issue and many countries tend to be reluctant to take initiatives challenging long-established attitudes or practices. It can take considerable political courage to try new approaches in areas such as policing and public security.

With all three of these problems, there is a strong role to be played by public health practitioners, academic institutions, nongovernmental organizations and international organizations, to help governments increase their knowledge of and confidence in workable interventions. Part of this role is advocacy, using education and science-based information. The other part is as a partner or consultant, helping to develop policies and design or implement interventions.

\section{Conclusion}

Public health is concerned with the health and well-being of populations as a whole. Violence imposes a major burden on that well-being. The objective of public health is to create safe and healthy communities around the world. A major priority today is to persuade all the various sectors - at the global, national and community levels - to commit themselves to this objective. Public health officials can do much to establish national plans and policies to prevent violence, building important partnerships between sectors and ensuring a proper allocation of resources to prevention efforts.

While public health leadership need not and indeed cannot direct all the actions to prevent and respond to violence, it has a significant role to play. The data at the disposal of public health and other agencies, the insights and understanding developed through scientific method, and the dedication to finding effective responses are important assets that the field of public health brings to the global response to violence. 


\section{Collaborations}

LL Dahlberg and EG Krug have participated to an equal extent in the preparation of the present article.

\section{References}

1. JA Mercy, ML Rosenberg, KE Powell, CV Broome, WL Roper. Public health policy for preventing violence. Health Aff 1993; 12:7-29.

2. World Health Organization. Global consultation on violence and health. Violence: a public health priority. Geneva: WHO; 1996 (document WHO/EHA/SPI. POA.2).

3. Walters RH, Parke RD. Social motivation, dependen$c y$, and susceptibility to social influence. In: Berkowitz L. Advances in experimental social psychology. v. 1. New York, NY: Academic Press; 1964. p. 231-76.

4. Dodge KA, Coie JD. Social information processing factors in reactive and proactive aggression in children's peer groups. J Pers Soc Psychol 1987; 53:114658.

5. Foege WH, Rosenberg ML, Mercy JA. Public health and violence prevention. Curr Issues Public Health $1995 ; 1: 2-9$.

6. Kruger J, Butchart A, Seedat M, Gilchrist A. A public health approach to violence prevention in South Africa. In: Van Eeden R, Wentzel M, editors. The dynamics of aggression and violence in South Africa. Pretoria: Human Sciences Research Council; 1998. p. 399-424.

7. Houry D, Feldhaus KM, Nyquist SR, Abbott J, Pons PT. Emergency department documentation in cases of intentional assault. Ann Emerg Med 1999; 34: 715-9.

8. World Health Organization. Multi-country study on women's health and domestic violence. Geneva: WHO; 1999. (document WHO/FCH/GWH/02.01).

9. Y Holder, M Peden, E Krug, J Lund, G Gururaj, O Kobusingye, editors. Injury surveillance guidelines. Geneva: WHO (published in collaboration with the United States Centers for Disease Control and Prevention), 2001 (document WHO/NMH/VIP/01.02).

10. Sethi D, Krug E, editors. Guidance for surveillance of injuries due to landmines and unexploded ordnance. Geneva: WHO; 2000. (document WHO/NMH/PVI/ 00.2).

11. Linda ES, Janet LF, Pamela MM, Gene AS. Intimate partner surveillance: uniform definitions and recommended data elements, Version 1.0. Atlanta, GA, National Center for Injury Prevention and Control, Centers for Disease Control and Prevention, 1999.

12. National Fatal Firearm Injury Statistics System Work Group. Uniform data elements for the National Fatal Firearm Injury Reporting System, Release 1.0. Boston, MA: Harvard Injury Control Research Center; 2000.

13. Center of Disease Control (CDC). Data elements for emergency departments. Atlanta, GA: National Cen- ter for Injury Prevention and Control, Centers for Disease Control and Prevention; 1997.

14. Dahlberg LL, Toal SB, Behrens CB. Measuring violence-related attitudes, beliefs, and behaviors among youths: a compendium of assessment tools. Atlanta, GA: Centers for Disease Control and Prevention; 1998.

15. World Health Organization. Putting women first: ethical and safety recommendations for research on domestic violence against women. Geneva: WHO; 2001 (document WHO/FCH/GWH/01.01).

16. World Health Organization. World health statistics annual 1996. Geneva: WHO; 1998.

17. Anderson RN. Deaths: leading causes for 1999. Natl Vital Stat Rep 2001; 49:1-87.

18. Heise LL, Ellsberg M, Gottemoeller M. Ending violence against women. Baltimore, MD: Johns Hopkins University School of Public Health, Center for Communications Programs, 1999 (Population Reports, Series L, No. 11).

19. Tjaden P, Thoennes N. Full report of the prevalence, incidence, and consequences of violence against women: findings from the National Violence Against Women Survey. Washington, DC: National Institute of Justice, Office of Justice Programs, United States Department of Justice and Centers for Disease Control and Prevention, 2000.

20. Rodgers K. Wife assault: the findings of a national survey. Juristat Service Bulletin 1994; 14:1-22.

21. El-Zanaty F, Hussein EM, Shawsky GA, Way AA, Kishor S. Egypt demographic and health survey, 1995. Calverton, MD: Macro International; 1996.

22. Randall M, Haskell L. Sexual violence in women's lives: findings from the women's safety project. A community-based survey. Violence Against Women 1995; 1(1):6-31.

23. Ellsberg MC, Pena R, Herrera A, Liljestrand J, Winkvist A. Candies in hell: women's experience of violence in Nicaragua. Soc Sci Med 2000; 51:1595-610.

24. Mooney J. The hidden figure: domestic violence in north London. London: Middlesex University; 1993.

25. Watts C, Keogh E, Ndlovu M, Kwaramba R. Withholding sex and forced sex: dimensions of violence against Zimbabwean women. Reprod Health Matters 1998; 6:57-65.

26. Grufman M, Berg-Kelly K. Physical fighting and associated health behaviours among Swedish adolescents. Acta Paediatr 1997; 86:77-81.

27. Kann L, Kinchen SA, Williams BI, Ross JG, Lowry R, Grunbaum JA, Kolbe LJ. Youth risk behavior surveillance: United States, 1999. Morbidity and Mortality Weekly Report, 2000, 49:1-104 (CDC Surveillance Summaries, SS-5). 
28. Gofin R, Palti H, Mandel M. Fighting among Jerusalem adolescents: personal and school-related factors. J Adolesc Health 2000; 27:218-23.

29. Miller TR, Cohen MA. Costs of gunshot and cut/stab wounds in the United States, with some Canadian comparisons. Accid Anal Prev 1997, 29:329-41.

30. Clayton D, Barcel A. The cost of suicide mortality in New Brunswick, 1996. Chronic Dis Can 1999: 20:8995.

31. Buvinic M, Morrison A. Violence as an obstacle to development. Washington, DC: Inter-American Development Bank 1999:1-8 (Technical Note 4: Economic and social consequences of violence).

32. Kaplan SJ, Pelcovitz D, Salzinger S, Weiner M, Mandel FS, Lesser ML, Labruna VE. Adolescent physical abuse: risk for adolescent psychiatric disorders. Am J Psychiatry 1998, 155:954-9.

33. Thompson MP, Meadows LA, Jacobs D, Chance S, Gibb B et al. Factors that mediate and moderate the link between partner abuse and suicidal behavior in African-American women. J Consult Clin Psychol 1998; 66:533-40.

34. Pederson W, Skrondal A. Alcohol and sexual victimization: a longitudinal study of Norwegian girls. Addiction 1996; 91:565-81.

35. Holmes MM, Resnick HS, Kilpatrick DG, \& Best CL. Rape-related pregnancy: estimates and descriptive characteristics from a national sample of women. Am J Obstet Gynecol 1996; 175:320-5

36. Kakar F, Bassani F, Romer CJ, Gunn SWA. The consequences of landmines on public health. Prehospital Disaster Med 1996; 11:41-5.

37. Toole MJ. Complex emergencies: refugee and other populations. In: Noji E, editor. The public health consequences of disasters. New York, NY: Oxford University Press 1997;419-42.

38. Garbarino J, Crouter A. Defining the community context for parent-child relations: the correlates of child maltreatment. Child Dev 1978; 49:604-16.

39. Bronfenbrenner V. The ecology of human development: experiments by nature and design. Cambridge: Harvard University Press; 1979.

40. Garbarino J. Adolescent development: an ecological perspective. Columbus, OH: Charles E. Merrill; 1985

41. Tolan PH, Guerra NG. What works in reducing adolescent violence: an empirical review of the field. Boulder, CO: University of Colorado, Center for the Study and Prevention of Violence, 1994.

42. Chaulk R, King PA. Violence in families: assessing prevention and treatment programs. Washington, DC: National Academy Press; 1998.

43. Heise LL. Violence against women: an integrated ecological framework. Violence Against Women 1998; 4:262-90.

44. Schiamberg LB, Gans D. An ecological framework for contextual risk factors in elder abuse by adult children. J Elder Abuse Negl 1999; 11:79-103.
45. Carp RM. Elder abuse in the family: an interdisciplinary model for research. New York: Springer; 2000.

46. Reiss AJ, Roth JA, editors. Violence in families: understanding and preventing violence. Panel on the understanding and control of violent behavior. Vol. 1. Washington: National Academy Press; 1993. p. 22145 .

47. Thornberry TP, Huizinga D, Loeber R. The prevention of serious delinquency and violence: implications from the program of research on the causes and correlates of delinquency. In: Howell JC, Krisberg B, Hawkins JD, Wilson JJ, editors. Sourcebook on serious, violent and chronic juvenile offenders. Thousand Oaks, CA: Sage; 1995. p. 213-37.

48. Lipsey MW, Derzon JH. Predictors of serious delinquency in adolescence and early adulthood: a synthesis of longitudinal research. In: Loeber R, Farrington DP, editors. Serious and violent juvenile offenders: risk factors and successful interventions. Thousand Oaks, CA: Sage; 1998. p. 86-105.

49. Maxfield MG, Widom CS. The cycle of violence: revisited 6 years later. Arch Pediatr Adolesc Med 1996; 150:390-5.

50. Farrington DP. The family backgrounds of aggressive youths. In: Hersov LA, Berger M, Shaffer D, editors. Aggression and antisocial behavior in childhood and adolescence. Oxford: Pergamon Press; 1978. p. 73-93.

51. McCord J. A forty-year perspective on the effects of child abuse and neglect. Child Abuse Negl1983; 7: 265-70.

52. Widom CS. Child abuse, neglect, and violent criminal behavior. Criminology 1989; 27:251-2-72.

53. Paolucci EO, Genuis ML, Violato C. A meta-analysis of the published research on the effects of child sexual abuse. J Psychol 2001;135:17-36.

54. Brown J, Cohen P, Johnson JG, Smailes EM. Childhood abuse and neglect: specificity of effects on adolescent and young adult depression and suicidality. J Am Acad Child Adolesc Psychiatry 1999; 38:1490-6.

55. Stark E, Flitcraft A. Killing the beast within: woman battering and female suicidality. Int J Health Serv 1995; 25:43-64.

56. Bristowe E, Collins JB. Family-mediated abuse of non-institutionalised elder men and women living in British Columbia. J Elder Abuse Negl 1989;1:4554.

57. Pillemer KA, Prescott D. Psychological effects of elder abuse: a research note. J Elder Abuse Negl 1989; 1:65-74.

58. Somasundaram DJ, Rajadurai S. War and suicide in Northern Sri Lanka. Acta Psychiatr Scand 1995; 91: $1-4$.

59. Tolan PH, Guerra NG. Prevention of juvenile delinquency: current status and issues. Appl Prev Psychol $1994 ; 3: 251-73$

Article presented in 30/03/2006 